\title{
The use of superparamagnetic nanoparticles for prosthetic biofilm prevention
}

\section{Erik N Taylor \\ Thomas J Webster}

Nanomedicine Laboratories, Division of Engineering, and Department of Orthopaedics, Brown University, Providence, RI 02912, USA
Correspondence: Thomas J Webster Associate Professor, Division of Engineering and Department of Orthopaedics, Brown University, 184 Hope Street, Providence, RI 029I2, USA Email thomas_webster@brown.edu
This article was published in the following Dove Press journal:

International Journal of Nanomedicine

II August 2009

Number of times this article has been viewed
Abstract: As with all surgical procedures, implantation comes with the added risk of infection. The goal of this in vitro study was to explore the use of superparamagnetic iron oxide nanoparticles (SPION) as a multifunctional platform to prevent biofilm formation. Results showed for the first time decreased Staphylococcus epidermidis numbers when exposed to $100 \mu \mathrm{g} / \mathrm{ml}$ of SPION for 12 hours and this trend continued for up to 48 hours. Prevention of colony assembly, a prerequisite to biofilm formation, was also observed at lower SPION dosages of $10 \mu \mathrm{g} / \mathrm{ml}$ after 12 hours. Coupled with previous studies demonstrating enhanced bone cell functions in the presence of the same concentration of SPION, the present results provided much promise for the use of SPION for numerous anti-infection orthopedic applications.

Keywords: superparamagnetic iron oxide nanoparticles (SPION), prosthetic infection, biofilm, nanotechnology, nanomedicine, Staphylococcus epidermidis

\section{Introduction}

Infection has been reported on an array of implantable devices including joint prostheses, central venous catheters and needleless connectors, endotracheal tubes, intrauterine devices, mechanical heart valves, pacemakers, peritoneal dialysis catheters, tympanostomy tubes, and voice prostheses. ${ }^{1}$ Importantly, in terms of orthopedics, $1.5 \%-2.5 \%$ of all hip and knee arthroplasties will become infected. ${ }^{2}$ Since prosthetic joint replacements are being used at an increasing frequency to alleviate pain, promote mobility, and improve the quality of life, the number of infected implants will only increase with time. Revision surgery may be required in such situations at an added cost and risk while resulting persistent deep tissue infection may require amputation. Joint prosthetic infection costs about US\$50,000 per episode and the associated mortality may be as high as $2.5 \% .^{2}$

A biofilm serves to promote bacteria persistence by resisting antibiotic treatment and host immune responses. Antibiotics are rendered ineffective when biofilms form due to their relative impermeability, the variable physiological status of microorganisms, subpopulations of persistent strains, and variations of phenotypes present. ${ }^{3}$ Protection of bacteria in biofilms from the innate immune system is mediated through electrostatic repulsion or proteolysis of antimicrobial peptides and prevention of phagocyte action. ${ }^{4,5}$

Nanotechnology may provide the answer to penetrate such biofilms and reduce biofilm formation. In addition, nanotechnology has been shown to promote tissue growth. For example, previous studies have indicated that $\gamma-\mathrm{Fe}_{2} \mathrm{O}_{3}$ superparamagnetic iron oxide nanoparticles (SPION) promoted osteoblast (bone-forming cells) metabolic 
functions when added to cell culture media. ${ }^{6}$ Furthermore, after coating these nanoparticles with calcium phosphate, a natural component of bone, a further increase in osteoblast functions were observed. ${ }^{6}$ Although there have been no animal studies to date examining the role of SPION in bone regeneration, iron restriction have been shown to impair osteoblast mineralization, while dietary iron intake has been shown to maintain healthy bone mineral density. ${ }^{7,8}$ Along this line, iron oxide nanoparticles may provide an effective means for biofilm treatment on orthopedic implants.

Moreover, the greatest numbers of bacteria in a biofilm are present at a nominal depth of about $10 \mu \mathrm{m} .{ }^{9,10}$ Penetration of a colloid to any depth in a biofilm is diffusion dependent with an inverse relationship to their size due to steric and mobility factors while plasma clearance plays a role in decreasing nanoparticle local concentration. ${ }^{11}$ Nanoparticles are small enough to penetrate the biofilm, large enough to have a long plasma half-life, and additionally offer a surface to volume ratio optimized for mass loading of targeting moieties, drugs, and antibiotics. ${ }^{9}$

Iron nanoparticles may offer some additional benefits for biofilm treatment. Iron restriction is closely related to the physiological onset of biofilm formation for common pathogenic bacteria such as Staphylococcus epidermidis, S. aureus, and Pseudomonas aeruginosa. Biofilm formation through polysaccharide intercellular adhesin (PIA) production by $S$. epidermidis and $S$. aureus is a stress response mechanism to conditions such as heat, anaerobic conditions, or iron-limited culture medium. ${ }^{12}$ Iron-limited medium can cause gene transcription in $S$. epidermidis, which results in the release of siderophores that mediate the covalent bonding of the bacterium to metal surfaces. ${ }^{13,14}$ Biofilm pathogenesis of $S$. aureus has been implicated by the expression of extracellular adherence protein (Eap) and extracellular matrix binding protein (Emp) which are induced by iron restriction. ${ }^{15}$ Most profoundly, biofilms grown from $P$. aeruginosa strains obtained in the sputum of cystic fibrosis patients have been disrupted and cleared by switching to iron-rich medium in flow chamber tests. ${ }^{16}$

To further explore the multifunctional use of SPION for orthopedic applications as a novel approach to prevent implant infection, a superparamagnetic nanoparticle platform is proposed here. Superparamagnetic nanoparticles are attractive for this purpose because antibiotic delivery can be carried out in the presence of a magnetic field. Biofilm targeting for this purpose could then be achieved through the conjugation of SPION to antibodies directed towards PIA with duel recognition of biofilms produced by common pathogens
(S. epidermidis and S. aureus). ${ }^{17}$ Finally, detection of bacteria could also be provided by enhanced $\mathrm{T} 2$-weighted magnetic resonance image contrast offered by targeted SPION if the particles enter the bacteria. ${ }^{18}$ However, as a first step in this direction, this study will explore the groundbreaking hypothesis that SPION alone (ie, without anti-infection drugs) may prevent biofilm formation.

\section{Materials and methods}

\section{$\mathrm{Fe}_{3} \mathrm{O}_{4}$ synthesis and preparation}

SPION synthesis was carried out as previously described. ${ }^{6}$ Briefly, iron(II) chloride and iron(III) chloride (Fisher Scientific Inc, Waltham, MA) at a ratio of 1:2 were added drop-wise into aqueous sodium hydroxide solutions resulting in a black precipitate. $\mathrm{The}_{\mathrm{Fe}} \mathrm{O}_{4}$ was collected in a magnetic field, decanted, and dispersed in 100\% ethanol several times. Three aliquots were taken from the solution, dried, and weighed to determine particle concentration.

\section{Nanoparticle characterization}

SPION were characterized with X-ray diffraction (XRD) to verify the phases present using $\mathrm{Cu} \mathrm{K} \alpha$ radiation (Siemens Diffractometer D5000 Kristalloflex; Bruker AXS Inc, Chicago, IL). The $2 \theta$ angle was varied from $20^{\circ}$ to $70^{\circ}$ at $10^{\circ} \mathrm{min}^{-1}$. Diffraction signal intensity was recorded and processed using DiffracPlus: TexEval software (Bruker AXS, Inc, Palo Alto, CA).

The magnetic properties (hysteresis loop) of the dried nanoparticles were assessed using vibrating sample magnetometry (VSM) (LakeShore 7400, Chicago, IL) at $300 \mathrm{~K}$. Briefly, for VSM, samples were centrifuged and the supernatant decanted. Nanoparticles were then dispersed in ethanol, centrifuged and the supernatant decanted. These nanoparticles were then allowed to dry at room temperature for several days. Powders were weighed and then placed in a capsule for magnetic readings.

Transmission electron microscopy (TEM) was used to visualize the morphology of the SPION. The dispersion of nanoparticles in deionized water was allowed to slowly dry on a formvar-coated copper grid. All imaging was carried out using a Philips JOEL 140 kV TEM (Philips, New York, NY) and size calculations were carried out using Image $J$ version 1.41 (National Institutes of Health, Bethesda, MD).

\section{S. epidermidis culture}

Bacteria used were $S$. epidermidis \#35984 obtained in freeze-dried form (American Type Culture Collection, Manassas, VA). The dry pellet was rehydrated in $6 \mathrm{ml}$ Luria 
broth (LB) consisting of $10 \mathrm{~g}$ tryptone, $5 \mathrm{~g}$ yeast extract, $5 \mathrm{~g} \mathrm{NaCl}$ (all obtained from Sigma, St. Louis, MO) per liter double distilled water with $\mathrm{pH}$ adjusted to 7.4. The solution was incubated $\left(37^{\circ} \mathrm{C}, 5 \% \mathrm{CO}_{2}\right.$, humidified environment) and agitated until the bacteria reached late stationary phase (about 24 hours). The second passage was diluted at a ratio of 1:200 into fresh LB and incubated until late stationary phase whereby it was mixed with equal proportions of $50 \%$ glycerol (Sigma) and frozen at $-18^{\circ} \mathrm{C}$.

\section{Bacteria growth}

Centrifuge tubes were prepared with $3 \mathrm{ml} \mathrm{LB}$ and inoculated with a sterile $10 \mu \mathrm{L}$ (Sigma) loop followed by agitation at 250 revolutions per minute $(\mathrm{rpm})$ until the bacteria culture reached stationary phase (about 18 hours). At that point, cells were diluted in LB to an optical density of 0.52 at $562 \mathrm{~nm}$ using a microplate reader. This value is equivalent to $30 \%$ absorbance correlating to a three on the McFarland Scale, or $9 \times 10^{8}$ bacteria per ml. Bacteria were further diluted and inoculated at $3 \times 10^{6}$ cells per well into 96 well flat-bottom culture plates.

SPION solutions in ethanol were centrifuged for 10 minutes at 13,000 rpm. The supernatant was decanted and SPION were redispersed in LB. Solutions were serially diluted to achieve concentrations of $2 \mathrm{mg} / \mathrm{mL}, 1 \mathrm{mg} / \mathrm{mL}$, $100 \mu \mathrm{g} / \mathrm{mL}$, and $10 \mu \mathrm{g} / \mathrm{mL}$ while $50 \mu \mathrm{L}$ of the decanted supernatant solution possibly containing iron salt and ethanol or LB only $(0 \mathrm{mg} / \mathrm{ml})$ served as supernatant controls during each 48 hour experiment. Optical density readings were taken using a microplate reader to determine bacteria number at 12-, 24-, and 48-hour time points.

\section{Bacteria live/dead staining}

After 48 hours of culture, plated bacteria were dispersed into culture media and transferred into microcentrifuge tubes. Bacteria were centrifuged at 10,000 rpm for two minutes after which the supernatant was discarded. Cell pellets were redispersed into $300 \mu \mathrm{L}$ tris buffer solution containing the BacLight Live/Dead solution (Life Technologies Corporation, Carlsbad, CA) at the concentration recommended by the manufacturer and placed onto microscope slides at a volume of $200 \mu \mathrm{L}$ before cover slips were applied for microscopy purposes. Prepared slides were allowed to dry for at least 24 hours before visualization.

\section{Bacteria viability and image analysis in situ}

After 48 hours of culture, in situ fluorescent images were taken to assess bacteria cluster formation and biofilm formation. Image-Pro Analyzer version 6.2 (Media Cybernetics, Inc., Bethesda, MD) was used to quantify either total fluorescent area (TFA) of live or dead bacteria or bacteria colonies. Bacteria colonies were counted as any object larger than a single cell. Similar to the above, red and green fluorscent stains corresponded to live or dead bacteria clusters, respectively.

\section{Statistical analysis}

All experiments were conducted in triplicate and repeated at least three times. Differences between means were determined using a Student's $t$-test (unpaired).

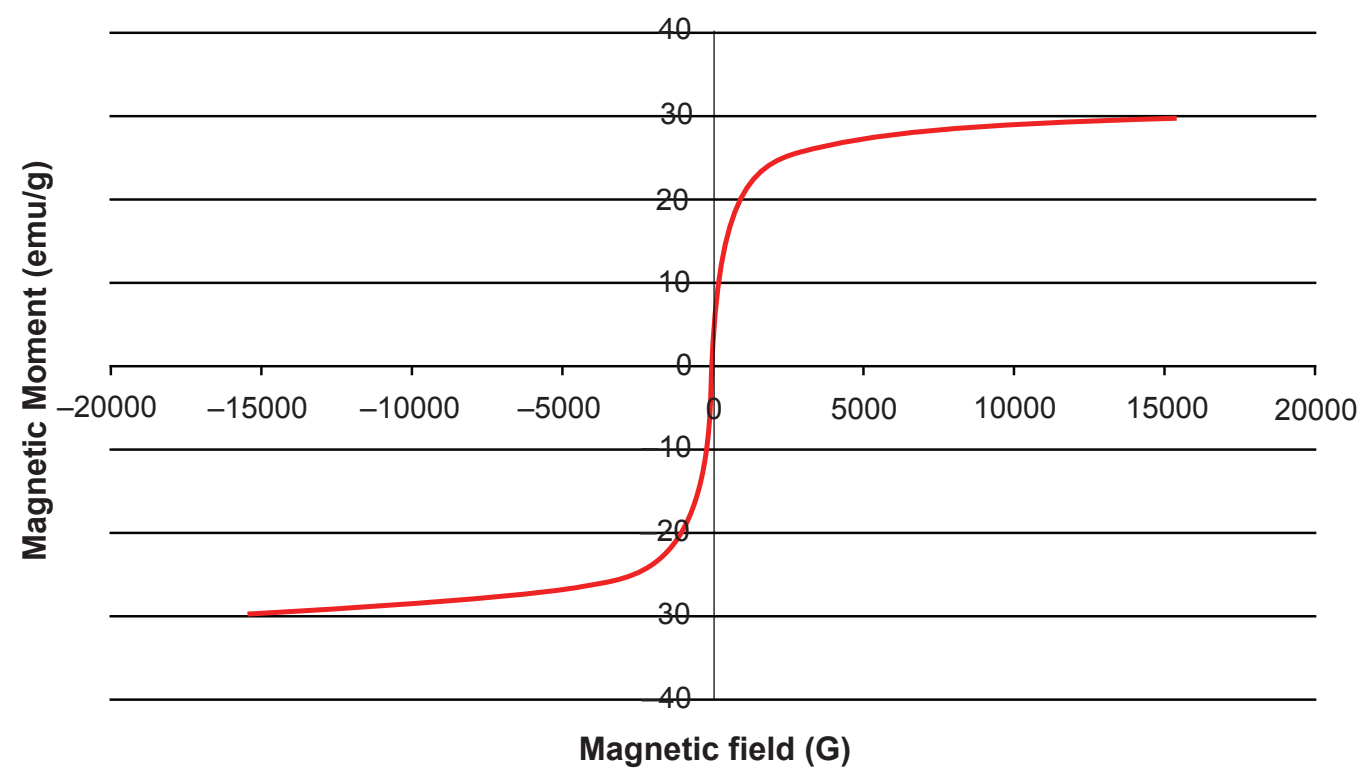

Figure I Magnetic properties of superparamagnetic iron oxide nanoparticles as determined by vibrating sample magnetometry. The nanoparticles are superparamagnetic and have a saturation magnetization of about 30 electromagnetic units per gram (emu/g). 


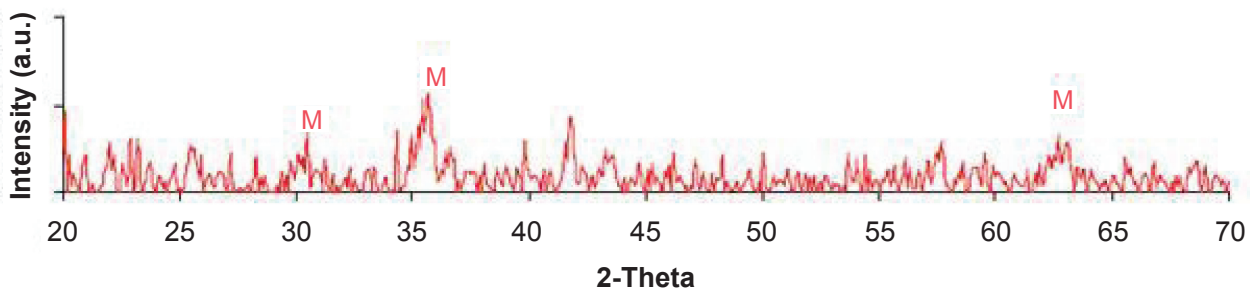

Figure 2 X-ray diffraction spectrum of the superparamagnetic iron oxide nanoparticle (SPION). Magnetite $\left(\mathrm{Fe}_{3} \mathrm{O}_{4}\right)$ peaks $(\mathrm{M})$ are shown confirming the crystalline phases of the SPION.

\section{Results}

\section{Nanoparticle characterization}

The SPION synthesized were superparamagnetic with very low hysteresis and a saturation magnetization around 30 electromagnetic units per gram (emu/g) (Figure 1). Diffraction peaks acquired matched with $\mathrm{Fe}_{3} \mathrm{O}_{4}$ (Figure 2). Electron microscopy visualization demonstrated that uncoated nanoparticles had a cubic structure with a maximum particle size of $18 \mathrm{~nm}$ and an average size of about $8 \mathrm{~nm}$ (Figure 3).

\section{Bacteria growth}

Optical density studies indicated progressively decreased S. epidermidis density at all time points (12-48 hours) when cultured with $100 \mu \mathrm{g} / \mathrm{mL}, 1 \mathrm{mg} / \mathrm{mL}$, and $2 \mathrm{mg} / \mathrm{mL}$ (Figure 4). This is in contrast with the low SPION concentration of $10 \mu \mathrm{g} / \mathrm{mL}$ for which no significant difference was observed compared to controls (no particles). The SPION supernatant control (possibly containing ethanol and iron salt) did not cause a decrease in bacteria density compared to no particle controls, thus, providing evidence that the iron

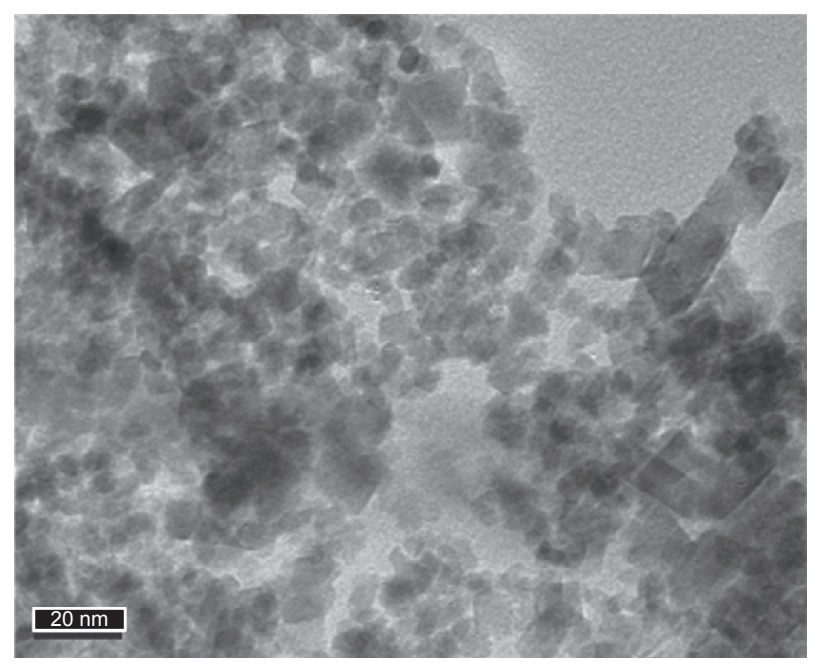

Figure 3 Transmission electron microscopy images of superparamagnetic iron oxide nanoparticles collected on a Philips JEOL at an operating voltage of $120 \mathrm{kV}$. oxide nanoparticles (not other chemicals used/created when fabricating such particles) decreased bacteria number.

\section{Bacteria viability in situ}

Fluorescence microscopy results demonstrated a higher percentage of dead bacteria when exposed to SPION after 48 hours (Figures 5-6). TFA quantification provided, for the first time, evidence that bacteria death increased in the presence of all SPION dosages of interest to this study (Figure 5). A significant increase in bacteria death occurred at SPION concentrations of $2 \mathrm{mg} / \mathrm{mL}, 1 \mathrm{mg} / \mathrm{mL}$, and $100 \mu \mathrm{g} / \mathrm{mL}$ compared to controls.

Fluorescent images of bacteria in the presence of various SPION concentrations confirmed previous results (Figure 7). Lastly, quantification of $S$. epidermidis with fluorescence microscopy indicated significantly higher percentages of dead bacteria (stained red) in the presence of all SPION solutions compared to controls $(0 \mathrm{mg} / \mathrm{ml})$ and the supernatant control condition (Figure 7; $10 \mu \mathrm{g} / \mathrm{mL}$ only shown).

\section{Discussion}

Proposed here is the hypothesis that iron oxide magnetic particles alone may prevent biofilm formation (Figure 8). Specifically, the antibacterial activity of magnetic nanoparticles was supported here by 48 hour live/dead bacteria studies showing significantly inhibited bacteria growth at $100 \mu \mathrm{g} / \mathrm{mL}$ or greater concentrations. Previous studies with metal oxides indicated that antibacterial activity could be mediated by hydrogen peroxide or superoxide anion free radical production. ${ }^{19,20}$ Free radical production results from the use of metal oxides due to metal ion release or through their interaction with UV light. ${ }^{20,21}$ Iron ions generate oxygen radicals by converting hydrogen peroxide to the more reactive hydroxyl radical via the fenton reaction. ${ }^{21}$ Hydroxyl radicals generated by these iron ions can depolymerize polysaccharides, cause DNA strand breaks, inactivate enzymes, and initiate lipid peroxidation. ${ }^{22}$ 


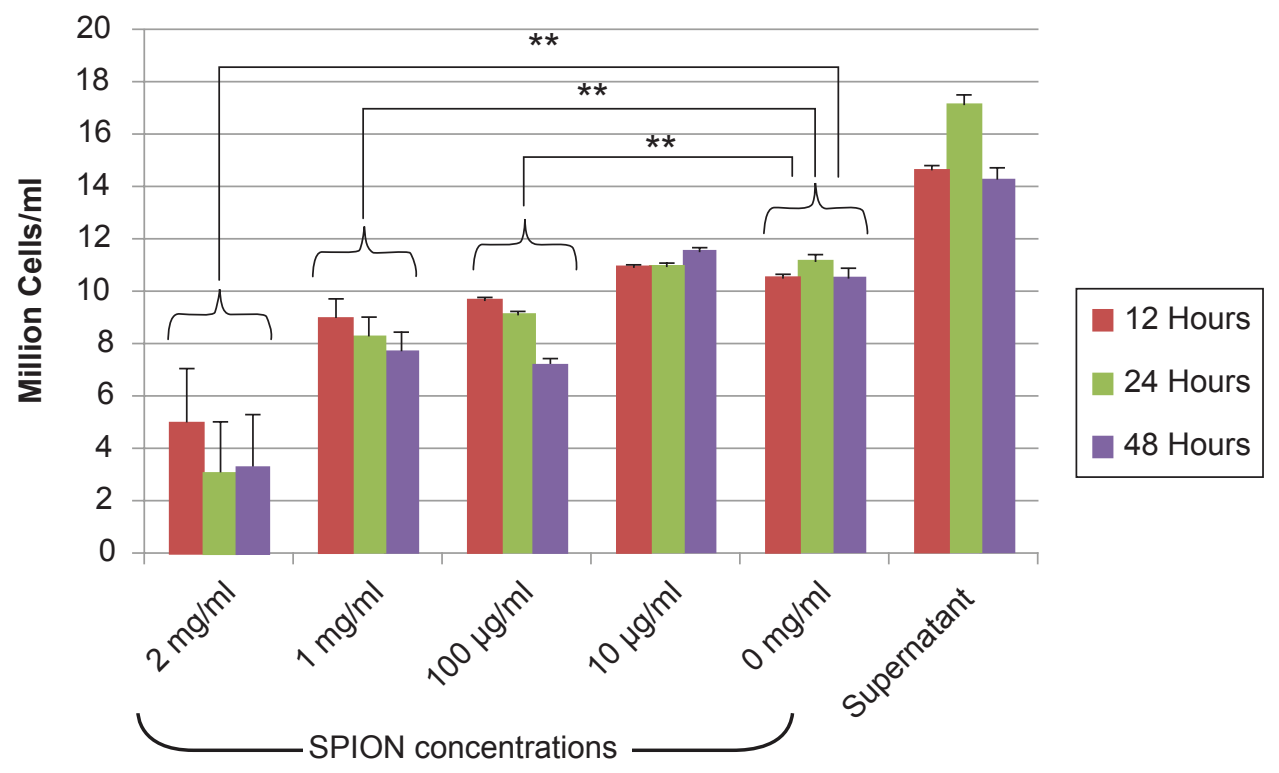

Figure 4 Decreased S. epidermidis numbers in the presence of superparamagnetic iron oxide nanoparticles. Cells were inoculated at $3 \times 10^{6}$ cells per well and were cultured for up to 48 hours. Data was obtained using optical density readings and each bar represents the average of 24 readings. Bacteria density decreased for doses as low as $100 \mu \mathrm{g} / \mathrm{ml}$ compared to no particles $(0 \mathrm{mg} / \mathrm{ml})$ at all time points assessed. The lowest dose, $10 \mu \mathrm{g} / \mathrm{ml}$, was not significantly different than controls (no particles).

Notes: All $\mathrm{P}$ values assessed at the $1 \%$ level are denoted **and error bars indicate standard error of the mean $(\mathrm{N}=3)$.

Moreover, nanoparticle binding to cell membrane or cell membrane proteins through electro-static interactions disrupting bacteria functions is another possible mechanism that may have caused bacterial death in this study. ${ }^{23-25}$ The adhesion of bacteria to iron oxide has been demonstrated for bulk iron oxide substrates in which greater bacterial adhesion has been observed to nonmetal surfaces such as glass. ${ }^{26}$ It is thought that for negatively charged bacteria, adhesion on metal oxides increases due to a positively charged surface. ${ }^{26}$
Yet, this conclusion lacks a consideration of the impact of greater surface energy on select protein and macromolecule adsorption in relation to decreased particle size. ${ }^{26,27}$ That is, the magnetic iron oxide nanoparticles fabricated here may have adsorbed proteins more favorable for binding to bacteria, further disrupting bacteria function leading to their death. ${ }^{23,25}$

$\mathrm{MgO}$ nanoparticles were tested against Escherichia coli and $S$. aureus where it was shown that of the $23,18,15,11$, and $8 \mathrm{~nm}$ particles, the smallest $8 \mathrm{~nm}$ particles decreased

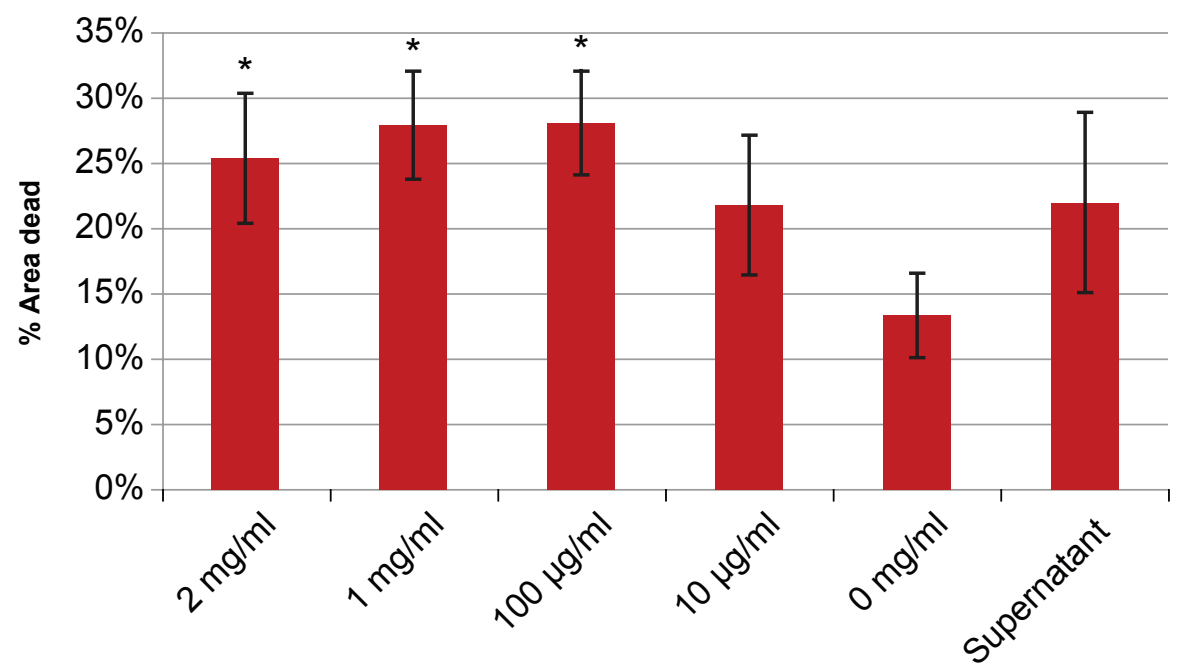

Figure 5 Percent of dead bacteria quantified using fluorescence microscopy after 48 hours. Total fluorescent area of bacteria cultures was determined for both green (live) and red (dead) regions and the average dead bacteria staining area for each is reported. A significant increase in dead cells was found for high superparamagnetic iron oxide nanoparticle doses compared to controls $(0 \mathrm{mg} / \mathrm{ml})$, but not for the $10 \mu \mathrm{g} / \mathrm{ml}$ or supernatant alone conditions.

Notes: All P values denoted with *are significant at the $5 \%$ level compared to controls and error bars are standard error of the mean $(\mathrm{N}=3)$. 

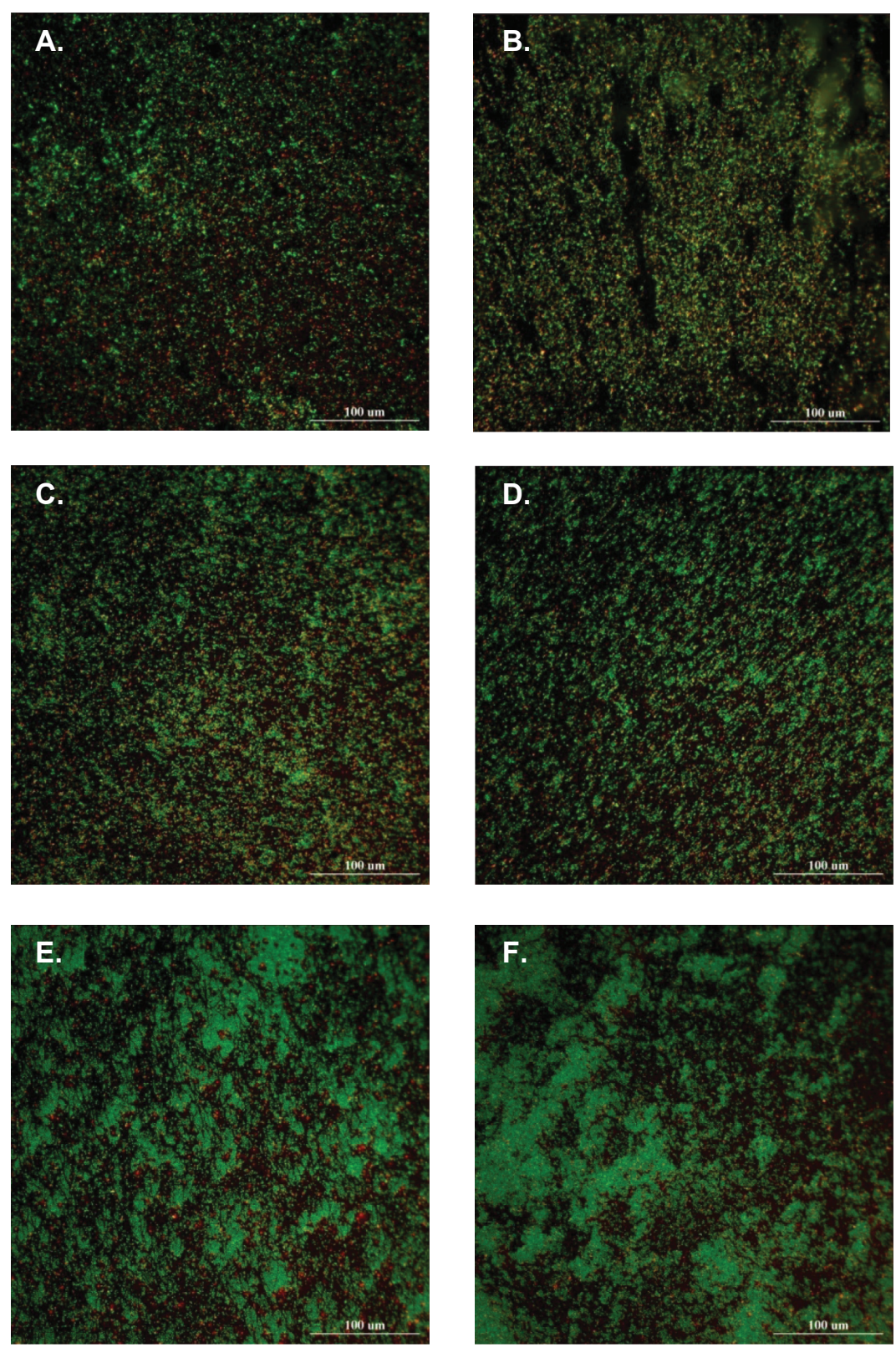

Figure 6 Fluorescently stained in situ bacteria colonies are inhibited as superparamagnetic iron oxide nanoparticle (SPION) concentration increased after 48 hours (living cells stained green). This was most obvious for the highest SPION concentrations of $2 \mathrm{mg} / \mathrm{ml}$ (A) and I $\mathrm{mg} / \mathrm{ml}$ (B). This effect occurred in a dose-dependent manner with $100 \mu \mathrm{g} / \mathrm{ml}$ (C) and $10 \mu \mathrm{g} / \mathrm{ml}$ (D) causing an intermediate amount of disruption to bacteria growth. Normal bacterial growth was seen with controls (E) and the supernatant conditions (F).

bacteria growth the most. ${ }^{23}$ Zinc oxide antibacterial activity has also been observed as particle size decreased to the nanometer level in cultures with $S$. aureus. ${ }^{25}$ This study showed that for $\mathrm{ZnO}$ ultrafine particles $(>1 \mu \mathrm{m})$ and nanoparticles $(50-70 \mathrm{~nm})$, a $50 \%$ decrease in bacteria activity was observed at $5 \mathrm{mM}$ concentrations; impressively, $8 \mathrm{~nm} \mathrm{ZnO}$ particles inhibited $99 \%$ of bacterial growth at $2 \mathrm{mM}$ concentrations. ${ }^{25}$ The particles used in this present study had an average size of about $8 \mathrm{~nm}$ and since less bacteria death was found here than in the previous study, it is important to mention that greater bone growth has been observed with those particles formulated in this study ${ }^{6}$ near the limit of those tested previous. To further improve the antibacterial function of the SPION formulated here, particles with an even lower average particle size should be fabricated as well as better dispersed particles.

Lastly, results from this study indicated bacteria colony disruption for SPION dosages as low as $10 \mu \mathrm{g} / \mathrm{mL}$. While this requires further investigation, this disruption of bacterial assembly may impact quorum sensing 


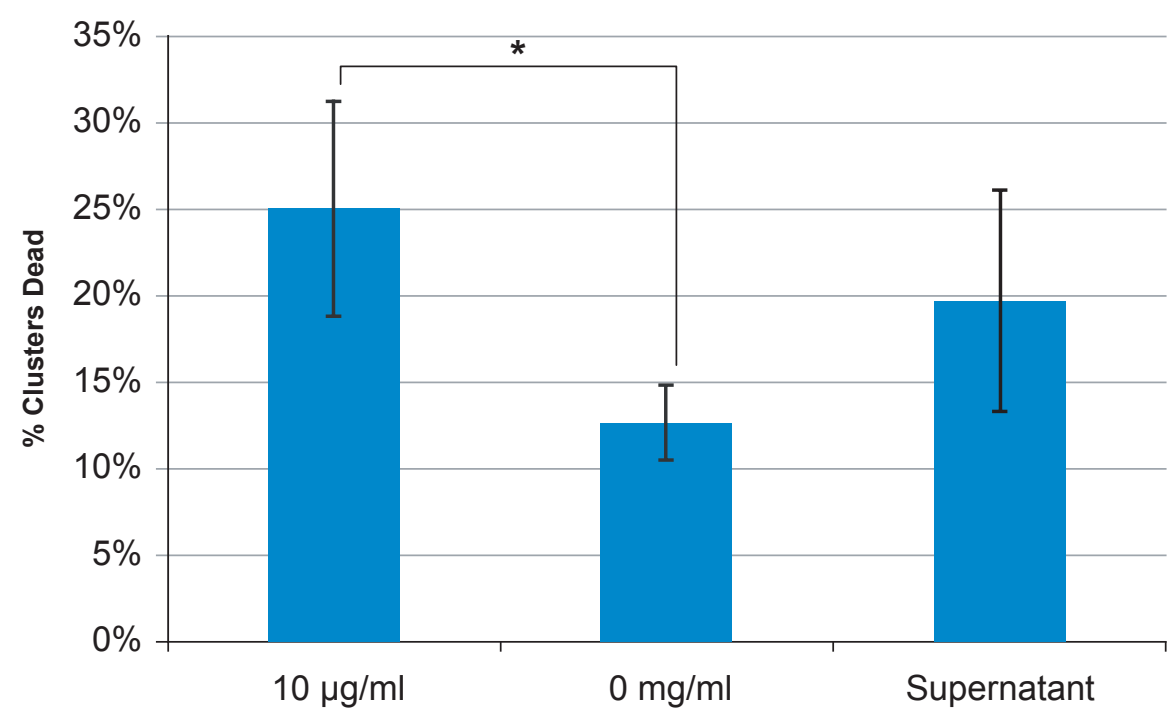

Figure 7 Greater percentages of dead bacteria clusters (or colonies) in the presence of superparamagnetic iron oxide nanoparticles as quantified in situ by fluorescence microscopy after 48 hours of culture.

Notes: The $\mathrm{P}$ value denoted with $*$ is significant at the $5 \%$ level compared to control and error bars are standard error of the mean $(\mathrm{N}=3)$.

and biofilm formation. ${ }^{28}$ This disruption could act synergistically with the other mechanisms explained above to prevent prosthetic biofilm formation.

\section{Conclusions}

In summary, in this study a novel minimally invasive nanotechnology-based treatment for fighting orthopedic implant infection through the use of SPION was considered. Bacteria culture density decreased at SPION dosages $100 \mu \mathrm{g} / \mathrm{mL}$ or greater were added to cultures. Inhibition of bacteria colony formation even with the lowest SPION dosages used here, $10 \mu \mathrm{g} / \mathrm{mL}$, was also found. These results indicated that when used alone, or coupled with other therapeutic agents, SPION could be useful to prevent biofilm formation.

\section{IOMN target biofilm}

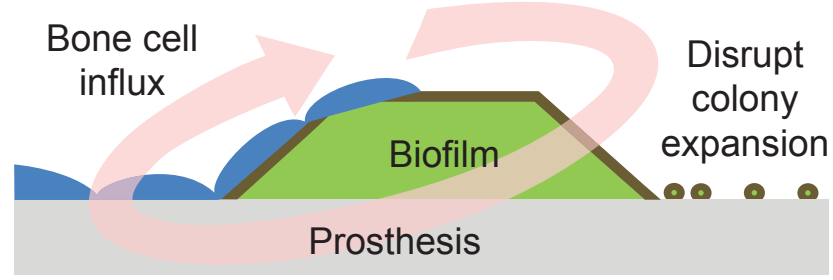

Figure 8 Schematic overview of an example of a multifunctional superparamagnetic iron oxide nanoparticle (SPION) for orthopedic applications. Polysaccharide intercellular adhesin antibody conjugation allows SPION to target bacteria. Bacteria death and bacteria colony disruption prevent bacteria growth and biofilm formation (mediated by SPION alone or in conjunction with other therapeutic agents, such as antibiotics). Bone cell function is subsequently increased by SPION presence or by customized nanoparticle coatings (such as calcium phosphate as shown in previous studies). ${ }^{6}$
This potential outcome provides a new paradigm for the treatment of persistent orthopedic implant infection using one multifunctional nanotechnology based platform. SPION can function as contrast agents allowing for the diagnoses of infection. Bacterial death caused by SPION alone or coupled with other antibiotics could decrease prosthesis infection. Decreased bacterial assembly could prevent biofilm formation and expansion. Finally, positive interactions between bone resident cells could be promoted by SPION alone or by using a customized surface coating. ${ }^{6}$ Therefore, it may be possible to diagnose, treat, and promote bone tissue regeneration at the site of orthopedic prosthesis infection.

\section{Acknowledgment}

The authors would like to thank the Hermann Foundation for financial support. The authors report no conflicts of interest in this work.

\section{References}

1. Donlan RM. Biofilms and device-associated infections. Emer Infect Dis. 2001;7:277-281.

2. Joseph RL. Prosthetic joint infections: Bane of orthopedists. Clin Infect Dis. 2003;36:1157-1161.

3. Hall-Stoodley L, Costerton JW, Stoodley P. Bacterial biofilms: From the natural environment to infectious diseases. Nature Rev Microb. 2004;2:95-108.

4. Vuong C, Voyich JM, Fischer ER, et al. Polysaccharide intercellular adhesin (PIA) protects Staphylococcus epidermidis against major components of the human innate immune system. Cell Microbiol. 2004;6:269-275.

5. Lai Y, Villaruz AE, Li M, et al. The human anionic antimicrobial peptide dermcidin induces proteolytic defence mechanisms in staphylococci. Mol Microbiol. 2007;63:497-506. 
6. Pareta RA, Taylor EN, Webster TJ. Increased osteoblast density in the presence of novel calcium phosphate coated magnetic nanoparticles. Nanotechnology. 2008;19:265101.

7. Abraham R, Walton J, Russell L, et al. Dietary determinants of postmenopausal bone loss at the lumbar spine: a possible beneficial effect of iron. Osteoporos Int. 2006;17:1165-1173.

8. Parelman M, Stoecker B, Baker A, et al. Iron restriction negatively affects bone in female rats and mineralization of hFOB osteoblast cells. Exp Biol Med (Maywood). 2006;231:378-386.

9. Suci PA, Berglund DL, Liepold L, et al. High-density targeting of a viral multifunctional nanoplatform to a pathogenic, biofilm-forming bacterium. Chem Biol. 2007;14:387-398.

10. Kadurugamuwa JL, Sin L, Albert E, et al. Direct continuous method for monitoring biofilm infection in a mouse model. Infect Immun. 2007;71:882-890.

11. Sanders NN, Smedt SC, Demeester J. The physical properties of biogels and their permeability for macromolecular drugs and colloidal drug carriers. J Pharm Sci. 2000;89:835-849.

12. Vuong C, Kidder JB, Jacobson ER, et al. Staphylococcus epidermidis polysaccharide intercellular adhesin production significantly increases during tricarboxylic acid cycle stress. J Bacteriol. 2005;187: 2967-2973.

13. Massonet C, Pintens V, Merckx R, Anné J, Lammertyn E, Van Eldere J. Effect of iron on the expression of sirR and sitABC in biofilm-associated Staphylococcus epidermidis. BMC Microbiol. 2006;6:103.

14. McWhirter MJ, Bremer PJ, Lamont IL, et al. Siderophoremediated covalent bonding to metal (oxide) surfaces during biofilm initiation by Pseudomonas aeruginosa bacteria. Langmuir. 2003;19: 3575-3577.

15. Johnson M, Cockayne A, Morrissey JA. Iron-regulated biofilm formation in Staphylococcus aureus Newman requires ica and the secreted protein Emp. Infect Immun. 2008;76:1756-1765.

16. Musk DJ, Banko DA, Hergenrother PJ. Iron salts perturb biofilm formation and disrupt existing biofilms of Pseudomonas aeruginosa. Chem Biol. 2005;12:789-796.
17. Cramton SE, Ulrich M, Götz F, et al. Anaerobic conditions induce expression of polysaccharide intercellular adhesion in Staphylococcus aureus and Staphylococcus epidermidis. Infect Immun. 2001;69: 4079-4085.

18. Felfoul O, Mohammadi M, Martel S. Magnetic resonance imaging of $\mathrm{Fe}_{3} \mathrm{O}_{4}$ nanoparticles embedded in living magnetotactic bacteria for potential use as carriers for in vivo applications. Conf Proc IEEE Eng Med Biol Soc. 2007;1463-1466.

19. Sawai J, Kawada E, Kanou F, et al. Detection of active oxygen generated from ceramic powders having antibacterial activity. JChem E Jap. 1996;29:627-633.

20. Jones N, Ray B, Ranjit KT, et al. Antibacterial activity of ZnO nanoparticle suspensions on a broad spectrum of microorganisms. FEMS Microbiol Lett. 2008;279:71-76.

21. Touati D. Iron and oxidative stress in bacteria. Arch Biochem Biophys. 2000;373:1-6.

22. Weinberg ED. Iron loading and disease surveillance. Emerg Infect Dis. 1999;5:346-352.

23. Makhluf S, Dror R, Nitzan Y, Abramovich Y, Jelinek R, Gedanken A. Microwave-assisted synthesis of nanocrystalline $\mathrm{MgO}$ and its use as a bacteriocide. Adv Funct Mater. 2005;15:1708-1715.

24. Stoimenov PK, Klinger RL, Marchin GL, et al. Metal oxide nanoparticles as bactericidal agents. Langmuir. 2002;18:6679-6686.

25. Zhang L, Jiang Y, Ding Y, et al. Investigation into the antibacterial behaviour of suspensions of $\mathrm{ZnO}$ nanoparticles ( $\mathrm{ZnO}$ nanofluids). Journal of Nanoparticle Research. 2007;9:479-489.

26. Li B, Logan BE. Bacterial adhesion to glass and metal-oxide surfaces. Colloids Surf B Biointerfaces. 2004;36:81-90.

27. Webster TJ, Schadler LS, Siegel RW, Bizios R. Mechanisms of enhanced osteoblast adhesion on nanophase alumina involve vitronectin. Tissue Eng. 2001;7:291-301.

28. Kong K, Vuong C, Otto M. Staphylococcus quorum sensing in biofilm formation and infection. Int J Med Microbiol. 2006;296:133-139.
International Journal of Nanomedicine

\section{Publish your work in this journal}

The International Journal of Nanomedicine is an international, peerreviewed journal focusing on the application of nanotechnology in diagnostics, therapeutics, and drug delivery systems throughout the biomedical field. This journal is indexed on PubMed Central, MedLine, CAS, SciSearch ${ }^{\circledR}$, Current Contents ${ }^{\circledR} /$ Clinical Medicine,

\section{Dovepress}

Journal Citation Reports/Science Edition, EMBase, Scopus and the Elsevier Bibliographic databases. The manuscript management system is completely online and includes a very quick and fair peer-review system, which is all easy to use. Visit http://www.dovepress.com/ testimonials.php to read real quotes from published authors. 